\title{
The Contribution of Virtual Reality to Social and Emotional Learning in Pre-Service Teachers
}

\author{
Eyal Weissblueth, Yonit Nissim \\ Faculty of Education, Ohalo Academic College, Qatzrin, Israel \\ Email: eyalw@ohalo.ac.il,yonitn@ohalo.ac.il
}

How to cite this paper: Weissblueth, E., \& Nissim, Y. (2018). The Contribution of Virtual Reality to Social and Emotional Learning in Pre-Service Teachers. Creative Education, 9, 1551-1564. https://doi.org/10.4236/ce.2018.910114

Received: July 10, 2018

Accepted: August 4, 2018

Published: August 7, 2018

Copyright (c) 2018 by authors and Scientific Research Publishing Inc. This work is licensed under the Creative Commons Attribution International License (CC BY 4.0).

http://creativecommons.org/licenses/by/4.0/

\section{cc (i) Open Access}

\begin{abstract}
This research focused on pre-service teachers' experiences in a virtual reality (VR) teaching unit that was included in a special course, "Educating for the Future," designed to enhance skills needed in the twenty-first century. The study examined how the trainees' experiences of working with VR affected their social and emotional learning. The research population included 176 students in their second year of a four-year training course to become teachers in the K-12 educational system. The research questions were whether teaching approaches employing VR have an impact on student teachers' social and emotional learning (SEL); and, if so, how collaboration in VR classroom activities and projects fosters learners' SEL. The study's main findings demonstrated that VR learning environments helped student teachers increase their social and emotional involvement in their learning and enabled them to become more innovative and creative as they harnessed the powers of VR. VR challenges learners with active teaching and learning and transforms student teachers into active participants who create and innovate.
\end{abstract}

\section{Keywords}

Virtual Reality, Emotions, SEL, Teachers, Creativity

\section{Introduction}

\subsection{VR in Education}

Several recent studies have demonstrated that there is an association between emotions and VR. VR has even been shown to act as an emotional amplifier, intensifying a wide range of positive or negative emotions and even emotional attachment to others. As a result, VR is an ideal tool for teaching and learning. 
The use of VR in schools requires to pedagogically consider times when students can become involved with both the creation of educational products creations and social and emotional learning (SEL). Previous studies focused on cognitive learning aspect of using VR in elementary and high school students, while the current research examined the effects of using VR on student teachers SEL before they began their teaching duties.

When used as an educational mode of learning and teaching, VR stimulates students' interest by its ability to engage them in otherwise impossible-to-experience situations and by its use of experimental tools delivered directly to students as virtual objects (Ahn \& Cho, 2015). By creating a virtual environment in which students can learn experientially about the real world in the past, present or future, VR offers a significant learning platform, which transcends conventional boundaries as place and space. In the context of a structured learning space in an educational setting, one of the goals of using VR is to transform the learning environment into a learning lab or online classroom. In doing so, the use of VR as an educational tool empowers abilities, learning skills, and creativity (Kim \& Ko, 2012).

Employing information and communication technologies (ICT) in the classroom turns learning and teaching more rich, innovative, and relevant. The literature is rich with descriptions of the successes of student teachers whose own teachers integrated educational themes corresponding to new subject matters relating to their academic disciplines, including that of VR, into their academic disciplines (Jestice \& Kahai, 2010; Nissim \& Weissblueth, 2017; Nissim, Weissblueth, Scott-Webber, \& Amar, 2016; Weissblueth et al., 2014).

There is a tendency to think that the use of visual explanations renders learning easier, as students find it easier to retain and recall images. VR is considered to be a motivational tool that makes learning a more active and involved process (Pantelidis, 2010). Some types of VR encourage or require collaboration, providing a supportive social environment. VR enables the learner to proceed through an experience at his or her own pace, enjoying a more expansive time frame not fixed or limited by a regular class schedule (Kim \& Ko, 2012).

\subsection{VR and Social and Emotional Learning}

Emotions play a significant role in teachers' activities and much of their work entails working with emotions. Clearly, the work of teaching has a high emotional component and, consequently, teachers must be able to effectively express emotional issues (Hochschild, 1983). Thus, it is essential to work with them on their emotional intelligence and abilities (Kremenitzer \& Miller, 2008). This can be done with many tools especially with pre-service teachers. These tools can increase awareness of the components of emotional intelligence and make teachers more conscious of what is happening to their students and to themselves.

Although the teacher training framework is designed to inculcate and foster teaching skills, a teacher's success also depends on personal abilities and sensi- 
tivity, which can be enhanced by introducing awareness of emotional intelligence components into the training process (Cherniss, 2000).

Social and Emotional Learning (SEL) is a comprehensive approach to student learning arising from the fields of developmental psychology and constructivism that aims to support the development of social and emotional competencies. SEL is also based on a number of theories and bodies of literature, including social-cognitive theory, social problem solving, moral and emotional development, resilience, self-determination theory, systems and ecological theory, and prevention science. SEL is a strength-based approach centered on encouraging students' development of specific key competencies: 1) Responsible decision-making: the ability to comprehend complex situations and make reasonable and ethical behavioral choices. 2) Self-management: appropriate expression and management of one's emotions in relation to the context. 3) Social awareness: awareness and understanding of the emotions and actions of others. 4) Relationship development: skills for successfully initiating, navigating and maintaining friendships and supportive relationships. 5) Self-awareness: awareness of one's emotions and behavioral patterns. The ways in which SEL is applied in schools are diverse, but the Collaborative for Academic and Social Emotional Learning (CASEL) suggested four ways in which SEL might be implemented, with examples of what these strategies look like in school settings. In a 2011 meta-analysis of 213 intervention studies, Durlak et al. (2011) found that SEL interventions implemented in schools resulted in 1) An increase in positive attitudes toward others, self, and school. 2) An increase in students' social-emotional skills. 3) An increase in positive behavior. 4) Improved academic achievement. 5) A significant reduction in emotional distress and problem behaviors.

Developments in VR technologies, including unobtrusive sensors and novel display devices, are advancing rapidly with the goal of VR as realistic as possible. However, there are many levels on which today's VR is still unable to create completely lifelike experiences. This deficiency is particularly apparent when introducing a social dimension into virtual worlds. Apparently, creating convincing virtual selves together with others, and conveying meaningful and appropriate social behavior, remains a continuing challenge for VR. This challenge involves both technical aspects of VR, such as the real-time capacities of the systems, and psychological aspects of the task, such as the dynamics of human communication. Our knowledge of VR systems is still fragmented with respect to social cognition, although the social dimension is crucial when targeting autonomous agents with discrete social background intelligence. The question can be raised, however, whether perfectly duplicating real-life interactions is a realistic or even meaningful goal of social VR development.

This study sought to test the SEL approach in a learning environment using VR. It focused on the emotional aspects of student teachers during training, which concentrated on constructing a three-dimensional educational product in a VR learning environment. Thus, the purpose of the current study was to ex- 
amine the possible contribution of VR to learning in the social and emotional domains (Weissberg et al., 2015). Research questions were whether teaching approaches employing VR have an impact on student teachers' social and emotional learning. If so, how do collaboration in VR classroom activities and projects foster learners' social and emotional learning? We hypothesized that while working on their VR assignments and projects, students would relate their experiences to their personal emotional and social situations. In addition, it was expected that the students would experience difficulties and a range of emotions while carrying out their assignments and ultimately succeed.

\section{Method}

\subsection{Research Population}

Prior to beginning the study, approval was obtained from the College Institutional Review Board. The research population included 176 students during their first semester of the second out of a four-year training period to become teachers in the K-12 educational system. In the first and second year they studied introductory courses common to all study majors. Table 1 presents the students' distribution by their disciplines and teaching level.

The research method was based on the term student voice, which refers to considering how students' learning experiences influence learned content. The term student voice also denotes making students partners in monitoring and evaluating their progress in learning and in shaping their learning processes. This enables learners to be active, reflective and involved in the process of learning and pedagogic design. The aim of the study was to investigate the role played by digital technologies in creating a space that encourages listening to the student voice in an academic course (Seale et al., 2015).

\subsection{Research Tools}

The VR platform was based on an Open Simulator Diva Distro (0.8.2.1) installed on a computer with an i5 Intel $2.2 \mathrm{MHz}$ CPU, with $16 \mathrm{~Gb}$ RAM. The platform built a virtual world (see Figure 1) which allowed up to 20 avatars to work simultaneously prior to ascertaining delays in avatar movements. Unrestricted reflections written by students at the end of the assignment were analyzed qualitatively to extract central themes.

Table 1. Research population distribution by discipline and teaching level.

\begin{tabular}{cccccc}
\hline & \multicolumn{5}{c}{ Faculties and Departments } \\
\cline { 2 - 6 } Grade & Sciences \& Math & $\begin{array}{c}\text { Liberal } \\
\text { Arts }\end{array}$ & $\begin{array}{c}\text { Special } \\
\text { Education }\end{array}$ & $\begin{array}{c}\text { Physical } \\
\text { Education }\end{array}$ & Total \\
\hline $\mathrm{K}$ & - & 52 & 5 & - & 57 \\
$7-6$ & 7 & 37 & 9 & 49 & 119 \\
\hline
\end{tabular}




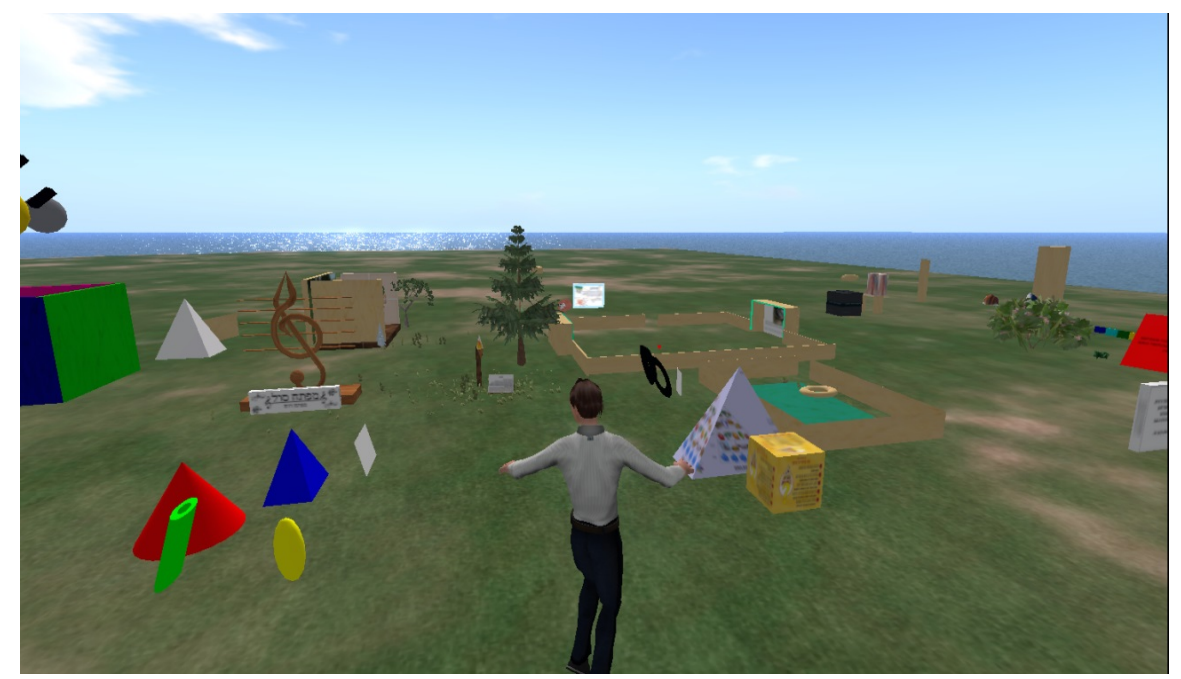

Figure 1. Part of the college's virtual world in which students created their 3D educational VR products.

\subsection{Process}

A qualitative research methodology was used, based on reflective narrative reports written by 176 preservice student teachers. Students participated in a course comprised of six units, designed to enhance their twenty-first-century skills in preparation for educational fieldwork in schools. The eight-hour, VR unit was aimed at enhancing the students' professional growth processes. The course introduced a learning module that required students to plan and build a three dimensional (3D) educational creation in a VR environment. While producing a $3 \mathrm{D}$ educational structure in a VR world they were required to be creative, to teach and learn online, to collaborate with their peers, to develop problem-solving strategies, and to cope with unfamiliar and sometimes complicated technical situations (see Figure 1 and Figure 2).

Every object appearing in the figure was created by students and accompanied by an explanation of its importance with regard to the purpose of learning how to harness the VR Open Simulator platform in the educational arena.

\subsection{Analysis}

A qualitative narrative analysis was employed in three phases (Miles et al., 2013). During the first phase of sorting and analysis, coding was used to create concise descriptor labels. The second phase involved code sorting and analysis to enable categorization and creation of themes. In the third phase, the results were interpreted and compared to the research hypotheses and model of SEL (Osher et al., 2016).

\section{Results}

Figure 2 shows examples of the educational VR creations that students created within their original projects. Several main themes emerged from the analysis 


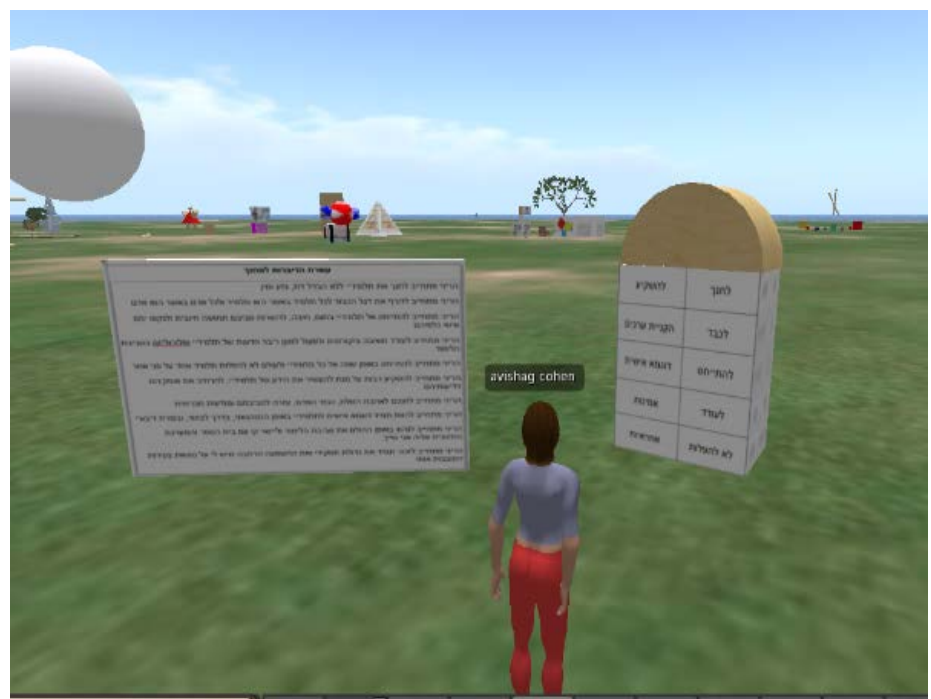

(a)

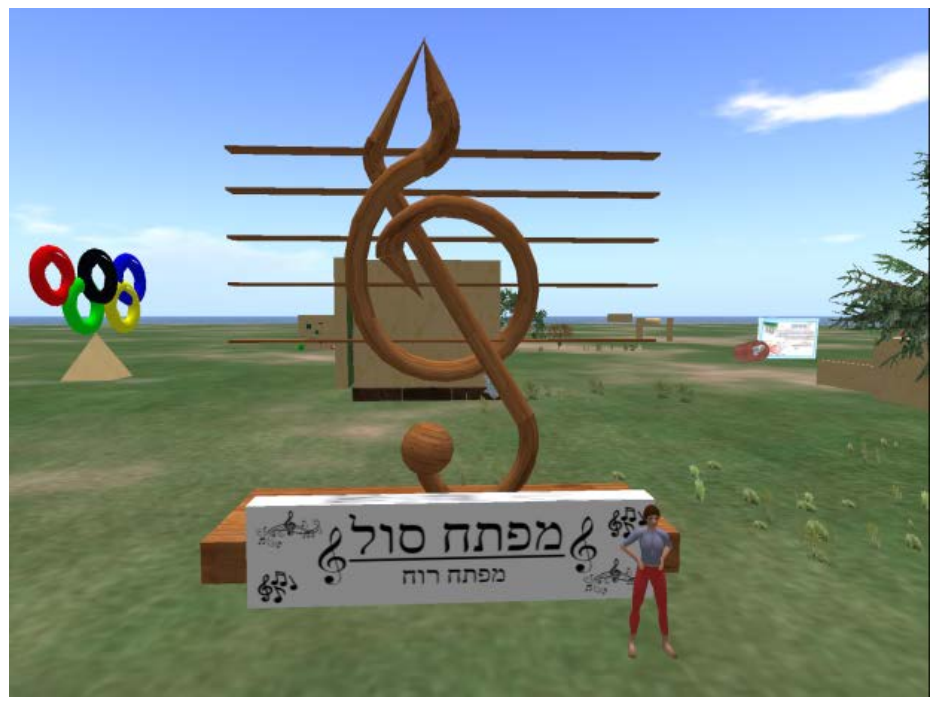

(b)

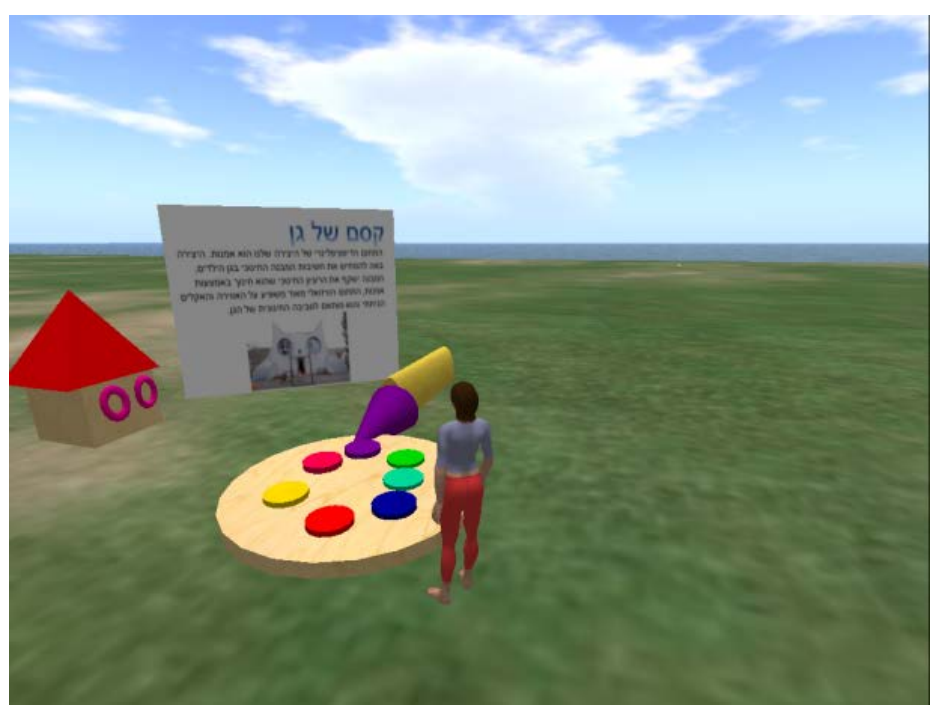

(c) 


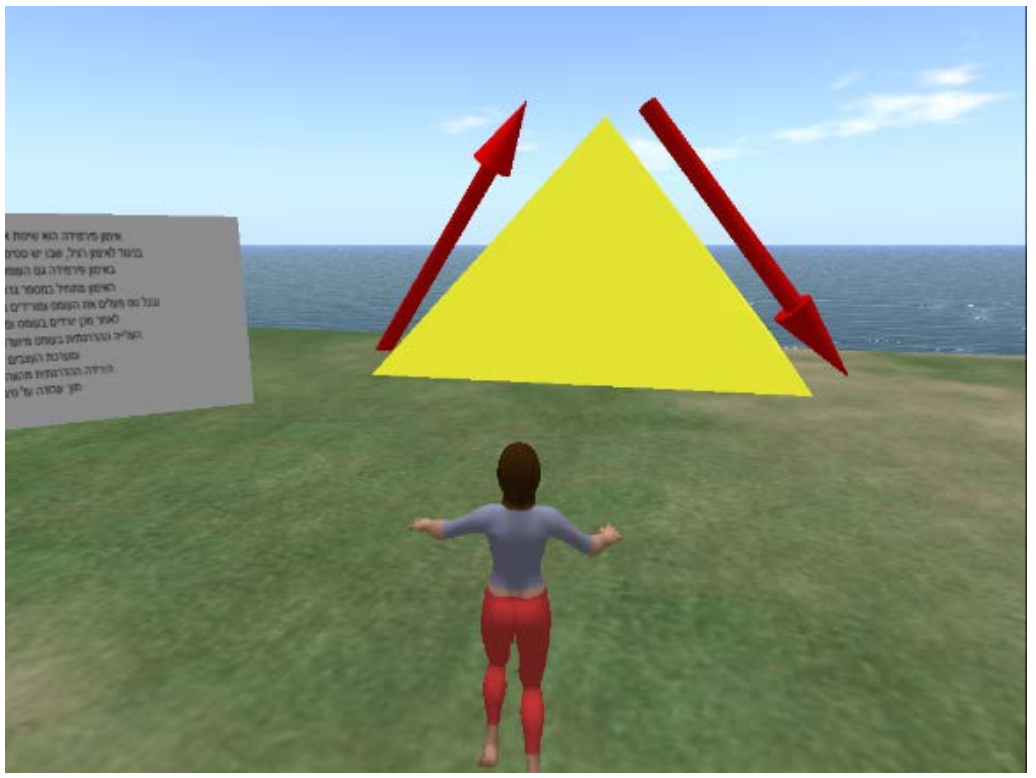

(d)

Figure 2. Four examples of original educational products in VR platforms: (a) Teacher-educator's ten commandments; (b) Key of sol in music as a key for teaching and education; (c) The wonders of kindergarten; (d) The ups and downs of the pyramid workout method of physical education.

and summaries of the reflections of the 176 participants. Two hundred and fifty-five reflection items were identified as related to the SEL categories of self-awareness (SeA), self-management (SM), social awareness (SoA), relationship skills (RS) and responsible decision making (RDM). Table 2 presents several examples in each category. Translated authentic expressions were maintained in their original student voice form. The analysis showed that learning in a VR environment creates SEL processes.

Student's reflections revolved mainly around their own emotions in the two SEL components of self-awareness (SeA), self-management (SM), social awareness (SoA), relationship skills (RS) and responsible decision-making (RDM). SeA and SM: 99 and 64 responses respectively. The remaining three SEL components, SoA, RS, and RDM had 27, 33 and 32 responses respectively. The results are summarized in Figure 3.

\section{Discussion}

The field of VR has flourished over the last decade. However, there is still a lack of research examining the different implications of working in a VR environment in the field of education. The results of the current study clearly demonstrate that VR elicits emotions, thoughts and a number of social interactions that are in accord with the SEL theory. Considering these findings, several issues should be addressed. These include the proportion of SEL components when employing VR, the effects on school-age students vs. teaching students, and the implications of using VR in schools. 
Table 2. Analysis of reflections from students in the course*.

\begin{tabular}{|c|c|c|c|}
\hline $\begin{array}{l}\text { Main } \\
\text { Category }\end{array}$ & $\begin{array}{l}\text { Secondary } \\
\text { Category }\end{array}$ & $\begin{array}{l}\text { Absolute Number of } \\
\text { Reflection Items (\%) }\end{array}$ & Example of Reflection Items \\
\hline \multirow{5}{*}{$\begin{array}{l}\text { Self } \\
\text { awareness } \\
(\text { SeA })\end{array}$} & $\begin{array}{l}\text { Classifying one's } \\
\text { feelings }\end{array}$ & $27(11)$ & $\begin{array}{l}\text { "At first, it was very hard to think of one thing that would focus me and answer all the } \\
\text { requirements. After thinking for a (long) while, I came to the conclusion that the course } \\
\text { was very challenging for me ... but after dealing with every subject, it became very easy." }\end{array}$ \\
\hline & $\begin{array}{l}\text { Relating feelings } \\
\text { and thoughts to } \\
\text { behavior }\end{array}$ & $11(4)$ & $\begin{array}{l}\text { "In a virtual environment, it is possible to make mistakes without suffering consequences. } \\
\text { The student is placed inside the activity and causes the action itself to take place." } \\
\text { "I was amazed to discover the advantages of virtual reality for those with special needs: } \\
\text { flexibility, motivation, independence, security and active learning experiences." }\end{array}$ \\
\hline & $\begin{array}{l}\text { Accurate } \\
\text { self-assessment } \\
\text { of strengths and } \\
\text { challenges }\end{array}$ & $38(15)$ & $\begin{array}{l}\text { "First of all, it's important for me to note that in this course, I unequivocally discovered } \\
\text { my strengths and weaknesses. There is no question that I had difficulty with some of the } \\
\text { tasks." }\end{array}$ \\
\hline & Self-efficacy & $16(6)$ & $\begin{array}{l}\text { "I think the table helped me a lot in reaching the outcome. At first, I did not know what I } \\
\text { wanted and I was confused, but finally, by adding additional columns to the table, I got } \\
\text { what I wanted." }\end{array}$ \\
\hline & Optimism & $7(3)$ & $\begin{array}{l}\text { "I started searching the internet for all kinds of topics in our everyday life, and this time I } \\
\text { was optimistic that I would find something meaningful with an educational message or } \\
\text { educational content-something that would give me a good feeling, or actual pleasure to } \\
\text { work with." }\end{array}$ \\
\hline \multirow{7}{*}{$\begin{array}{l}\text { Self } \\
\text { Management } \\
\quad(\mathrm{SM})\end{array}$} & $\begin{array}{l}\text { Regulating one's } \\
\text { emotions }\end{array}$ & $7(3)$ & $\begin{array}{l}\text { "Despite the burden of planning this assignment and the other tasks, and despite the fact } \\
\text { that I am afraid every time I start a new task, I am glad to have had the opportunity to } \\
\text { plan activities from different fields using various aids." }\end{array}$ \\
\hline & Managing stress & $6(2)$ & $\begin{array}{l}\text { "The thinking process began with frustration and pressure. I did not understand what } \\
\text { was expected of me in this task, or how this creation would look in the end, especially } \\
\text { since I really do not connect to the technological aspect of the lesson, which made it } \\
\text { difficult for me to think about creating. Later, when I found an idea, everything went } \\
\text { smoothly, and I even found myself connecting to a serious place within me, and had a } \\
\text { desire to pass on the message." }\end{array}$ \\
\hline & & & $\begin{array}{l}\text { "In the virtual world task, I could not understand why I was doing this and where it } \\
\text { would lead me, so there were quite a few difficulties. Eventually, to my great joy, I }\end{array}$ \\
\hline & & & managed to overcome them, and I was able to carry out the task in the best way possible." \\
\hline & Self-control & $43(17)$ & $\begin{array}{l}\text { "The table was excellent and helped me focus the idea and see a whole picture: what I } \\
\text { wanted to achieve, what it gave me and how it connects to my personal life." } \\
\text { "I came up with a number of ideas for learning about the mathematics of one through ten } \\
\text { in relation to the daily routine of kindergarten teachers and children. I felt that I was } \\
\text { competent in this task." }\end{array}$ \\
\hline & Self-motivation & $6(2)$ & $\begin{array}{l}\text { "I would like to point out that the instructions in the model were detailed and easy to } \\
\text { understand, which helped to replace apprehension with a sense of confidence and } \\
\text { motivation." }\end{array}$ \\
\hline & $\begin{array}{l}\text { Setting and } \\
\text { achieving goals }\end{array}$ & $2(1)$ & $\begin{array}{l}\text { "We decided to plan a creation that ..." and "...that the creation should be used in various } \\
\text { ways." }\end{array}$ \\
\hline \multirow[t]{3}{*}{$\begin{array}{l}\text { Social } \\
\text { Awareness } \\
\text { (SoA) }\end{array}$} & $\begin{array}{l}\text { Perspective } \\
\text { taking }\end{array}$ & $6(2)$ & $\begin{array}{l}\text { "I found this task very creative and interesting. It expands horizons and encourages } \\
\text { students to look at their work from several different perspectives." } \\
\text { "The pyramid represents my group members and me as a whole, with each of us } \\
\text { contributing to the process and helping to reach the complete product." }\end{array}$ \\
\hline & Empathy & $-(0)$ & \\
\hline & $\begin{array}{l}\text { Respecting } \\
\text { diversity }\end{array}$ & $11(4)$ & $\begin{array}{l}\text { "Another good thing is that this task gave every member of the group a place to express } \\
\text { themselves and their desires for educational creativity. After each person had built the } \\
\text { table individually and thought about the things that were important to him or her, we } \\
\text { tried to formulate an integrated creation that would represent a combination of all our } \\
\text { goals. In my opinion, this is an important part of the success of the work." }\end{array}$ \\
\hline
\end{tabular}




\begin{tabular}{|c|c|c|c|}
\hline & Understanding & & suitable for what we had learned. This made me very happy." \\
\hline & $\begin{array}{l}\text { social and } \\
\text { ethical norms of } \\
\text { behavior }\end{array}$ & $7(3)$ & $\begin{array}{l}\text { "In addition, the very fact that this task was first individual, with the ideas discussed } \\
\text { afterwards as a group, provided an opportunity for success. I believe that the format of } \\
\text { sitting as a group and raising a number of ideas allows room for discussion and reflection } \\
\text { on each of the ideas, and for arriving at a comprehensive conclusion about which } \\
\text { educational creation is most worthwhile or suitable for us to create as a group." }\end{array}$ \\
\hline & $\begin{array}{l}\text { Recognizing } \\
\text { family, school } \\
\text { and community } \\
\text { support }\end{array}$ & $3(1)$ & $\begin{array}{l}\text { "Before I chose which piece to do, my teammates and I consulted among ourselves and } \\
\text { each suggested a different idea. When I chose this piece and discussed it in the group, it } \\
\text { gave us more ideas for different creations based on this subject (the stages of success). It } \\
\text { was very easy to explain what is in the work." } \\
\text { "We needed to be creative, and this required more work and investment in others. I } \\
\text { enjoyed working with them during our time together." }\end{array}$ \\
\hline \multirow{5}{*}{$\begin{array}{l}\text { Relationship } \\
\text { Skills (RS) }\end{array}$} & $\begin{array}{l}\text { Building } \\
\text { relationships } \\
\text { with diverse } \\
\text { individuals and } \\
\text { groups }\end{array}$ & $3(1)$ & $\begin{array}{l}\text { "I chose a puzzle with different and varied parts, representing every one of us, with the } \\
\text { whole picture as a goal. All parts must be assembled in order to create the whole, to } \\
\text { accept our diversity, to cooperate, to work as a team, to support each other and to } \\
\text { empower each other. None of the pieces can be found outside the puzzle or outside the } \\
\text { whole picture. The purpose of the work is 'all for one and one for all." }\end{array}$ \\
\hline & $\begin{array}{l}\text { Working } \\
\text { cooperatively }\end{array}$ & $3(1)$ & $\begin{array}{l}\text { "... Although each of us had a final framework and a clearly defined goal, we helped each } \\
\text { other find the way there. The group dynamics and personal mobilization of the group } \\
\text { members were noteworthy." }\end{array}$ \\
\hline & $\begin{array}{l}\text { Communicating } \\
\text { clearly }\end{array}$ & $16(6)$ & $\begin{array}{l}\text { "Consultation with the group was fruitful and interesting; Each of us helped the other } \\
\text { focus, contributed to everyone's strengths and personality structure." }\end{array}$ \\
\hline & $\begin{array}{l}\text { Resolving } \\
\text { conflicts }\end{array}$ & $4(2)$ & $\begin{array}{l}\text { "I felt that the other students in my group were also in control of this task, understood } \\
\text { this mission, and offered brilliant ideas. It was very difficult for us to choose which idea } \\
\text { to pursue." }\end{array}$ \\
\hline & Seeking help & $7(3)$ & $\begin{array}{l}\text { "I noticed that we needed the group's consultation, support and cooperation. } \\
\text { Consultation with the group was fruitful and interesting. The group dynamic and } \\
\text { individual contributions of each team member were remarkable and we enjoyed it." }\end{array}$ \\
\hline \multirow{5}{*}{$\begin{array}{l}\text { Responsible } \\
\text { Decision } \\
\text { Making } \\
\text { (RDM) }\end{array}$} & $\begin{array}{l}\text { Considering the } \\
\text { well-being of self } \\
\text { and others }\end{array}$ & $10(4)$ & $\begin{array}{l}\text { "I hope that I will be able to express all of what we have learned by using this software. I } \\
\text { can create interest as well as a valuable and important educational dimension for the } \\
\text { viewer through this unique work." }\end{array}$ \\
\hline & $\begin{array}{l}\text { Recognizing } \\
\text { one's } \\
\text { responsibility to } \\
\text { behave ethically }\end{array}$ & $1(0)$ & $\begin{array}{l}\text { "This symbolizes the natural, inborn need of man for society as opposed to loneliness. It } \\
\text { is based on the biblical source in Genesis } 2: 188 \text {. The symbol is presented in a light, simple } \\
\text { way that is accessible to students, accompanied by an explanation of the overall idea. My } \\
\text { goal was that when the students see the symbol and the explanation presented, they will } \\
\text { understand the idea and the need for creating one, unified human society for all of us." }\end{array}$ \\
\hline & $\begin{array}{l}\text { Basing decisions } \\
\text { on safety, social } \\
\text { and ethical } \\
\text { considerations }\end{array}$ & $17(7)$ & $\begin{array}{l}\text { "When I look at contemporary reality, I see that we live in an environment saturated with } \\
\text { products. As educators for the future, it is important that we acquire many varied tools } \\
\text { for creating new products that are relevant to our lives and the lives of our students, and } \\
\text { that we reflect on the implications of these products independently, critically and in } \\
\text { depth." }\end{array}$ \\
\hline & $\begin{array}{l}\text { Evaluating } \\
\text { realistic } \\
\text { consequences of } \\
\text { various actions }\end{array}$ & $2(1)$ & $\begin{array}{l}\text { "Of course, the use of technology allows us to prepare for the future and understand the } \\
\text { uses of all kinds of important technological inventions." }\end{array}$ \\
\hline & $\begin{array}{l}\text { Making } \\
\text { constructive safe } \\
\text { choices for self, } \\
\text { relatives, and } \\
\text { schools }\end{array}$ & $2(1)$ & $\begin{array}{l}\text { "I think that it can help students change their way of thinking for the better and not give } \\
\text { up. The work will show students that success can come from many processes. It starts } \\
\text { with a low level and requires investment and time. In the end, you see high achievements } \\
\text { and that it was worth all the effort." }\end{array}$ \\
\hline
\end{tabular}

*Note that reflections were made according to SEL Model Categories and Subcategories Related to their Perceived Challenges and Benefits. 


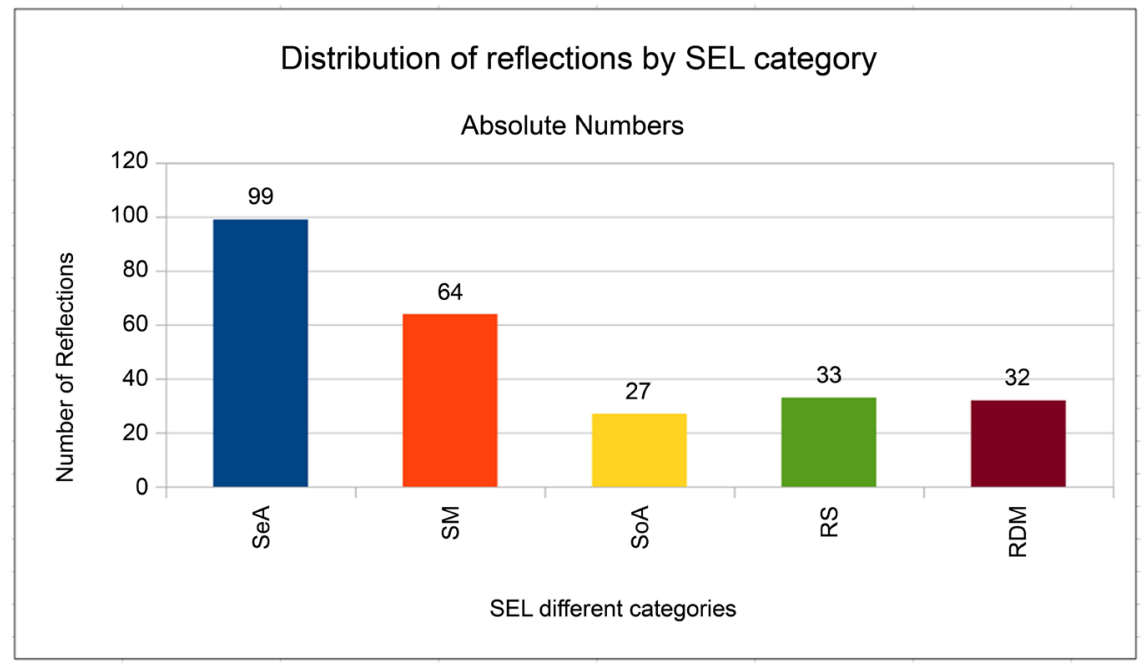

(a)

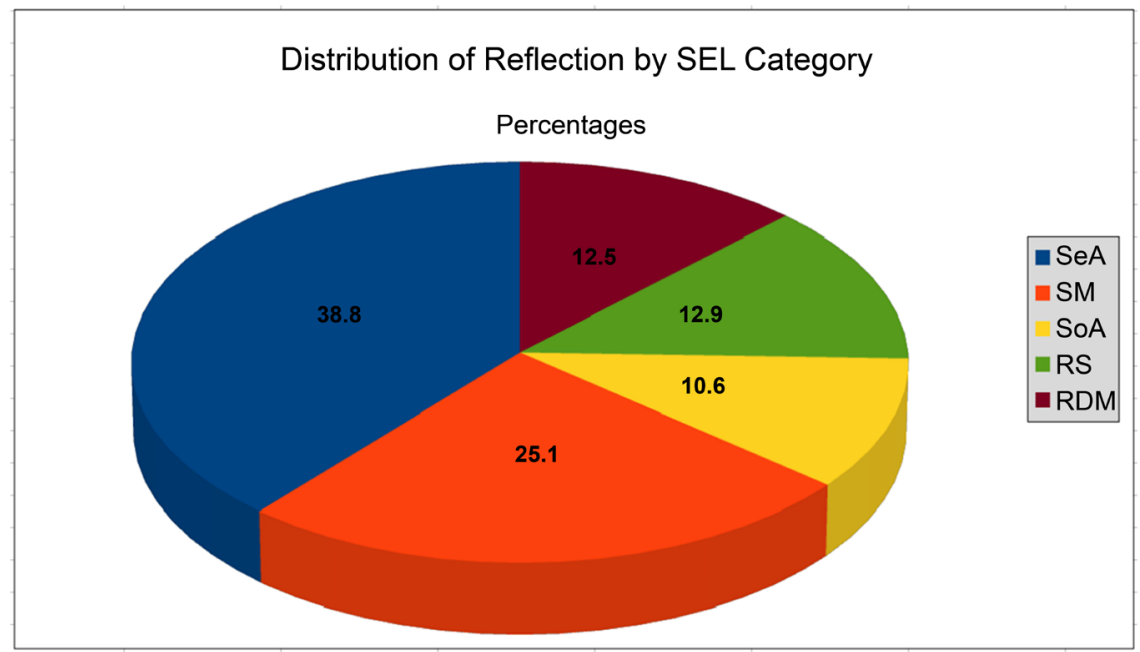

(b)

Figure 3. Distribution of reflections according to SEL category: (a) Absolute numbers; (b) Percentages.

\subsection{The Proportion of SEL Components When Employing VR}

Most participants' reflections recounted experiencing various emotions on a spectrum ranging from frustration, confusion and lack of understanding to great satisfaction, empowered self-sufficiency and strengthened personal and team resources. These findings support the hypothesis that students would experience a variety of feelings, emotions, difficulties, and successes while working in a VR environment. It can be argued that the collective components of teamwork in a social environment or peer group were important, both in terms of the number of statements (quantitative) and the emotional expressions relating to the support, success, and self-efficacy of group interaction. Individuals who participated in collaborative work were able to perform diverse tasks in the VR environment in an improved, more relaxed and creative manner. The social atmosphere proved fertile and productive and promoted learning. Moreover, when working 
together, participants found it easier to tackle complex technological tasks in the VR environment. The finding that most participants' reflections revolved around SA and SM and not around SoA, RS and RDM can be explained by the linearity of the phases in the SEL model, where self-oriented emotions and their management occur in the initial stages. Only after the individual has had sufficient experiences in self-awareness and self-management scenarios does the ability to be aware of society and its requirements develop. Our unit of VR provided for only a limited number of lessons to practice VR skills, thus not allowing sufficient time to develop more advanced SEL competencies.

\subsection{School-Age Students vs. Pre-Service Teachers}

This study sought to expand the perspective on various issues related to the connection between VR and SEL in the pre-service teacher training process and was not focused on elementary, middle and high school students. We observed that students who experienced learning in a VR environment exhibited a broad spectrum of emotions. Learning in this context, as in others, is based on emotions and feelings that arise when the social surroundings, teamwork, and material being learned relate to the real world, where professionalization is undoubtedly significant and meaningful. However, in the current study, learning resulted from the sense of being physically present in the non-physical world. Just as in previous studies (Annetta et al., 2009; Jones \& Park, 2015) where it was shown that students at the elementary and high school age relate to the virtual world as a physical one, it is reasonable to assume that they will also perceive the Open Simulator VR world as a physical one and learn just as well.

\subsection{Using VR in Pre-Service and In-Service Teacher Training}

Many researchers have concluded that using VR in its basic form in an Open Simulator platform suits schools better than other forms, such as 3D VR headsets. Not only does VR in an Open Simulator platform have financial, technological and health advantages (Inman et al., 2010; LaViola Jr., 2000; Merhi et al., 2007; Warburton, 2009), but its user-friendly 2D computer screen properties are also highly beneficial, allowing students to feel in control by simply disengaging from the computer screen. As a result, students can easily interact, share and collaborate in reality and in VR in an integrated fashion.

In the present study, the way in which students coped with the demand to produce an educational creation containing their personal significant content in VR while presenting social and emotional components identified in the SEL model, provide support to the importance of VR in teacher preparation and training. These findings are in accord with the findings of other researchers (e.g., Dieker et al., 2014; Jarmon et al., 2009; Jestice \& Kahai, 2010; Twining, 2009) who found that virtual worlds such as the those with the Open Simulator platform are environments that enable and encourage learners to be active and to investigate disciplinary content matter while learning, particularly when they are 
applied to learning projects connected to the real, tangible world.

\section{Conclusion}

In conclusion, in a VR environment, SEL is facilitated by collaborative teamwork in carrying out tasks that transfer, replicate and connect between existing reality and VR. Working in a VR environment creates a stratified learning process that is supported by interdisciplinary transference, while the social infrastructure of VR makes it easier to cope with discrepancies between the virtual and real worlds, thus allowing for easier movement between them. Prominent in the verbal statements of most of the students is the emotional flooding they felt during the VR learning process. VR may convey students' emotions more easily. They related to experiencing a wide range of varied and conflicting emotions and recognition of strengths, weaknesses, and, significantly, of social aspects, such as the use of collective shared resources. It is fundamental for teachers to first comprehend the emotional aspects of both their students and of the learned content matter prior to getting students engaged in virtual worlds. In addition, it is important to reinforce resources for cooperation when planning and designing activities, and in anticipating the responses of students. It is our opinion that there is a need for significant expansion of this area of study to devise better training processes for the future of education using a VR environment in an active and experiential fashion.

\section{Limitations of the Study}

Our study had some limitations. First, the research population was limited to one cross-faculties course. Although cross-faculties, it was not considered representative of all pre-service teachers. In addition, the study was based on students' statements and on qualitative analysis of their reflections on the processes only. There is a need for innovative research tools that are suitable for studying innovation in general and VR environments in particular.

\section{Acknowledgements}

Research unit at Ohalo Academic College for funding some of this work.

\section{Conflicts of Interest}

The authors declare no conflicts of interest regarding the publication of this paper.

\section{References}

Ahn, H.-S., \& Cho, Y.-M. (2015). Analysis on the Effects of the Augmented Reality-Based STEAM Program on Education. Advanced Science and Technology Letters, 92, 125-130. https://doi.org/10.14257/astl.2015.92.26

Annetta, L., Mangrum, J., Holmes, S., Collazo, K., \& Cheng, M.-T. (2009). Bridging Reality to Virtual Reality: Investigating Gender Effect and Student Engagement on Learning through Video Game Play in an Elementary School Classroom. International Jour- 
nal of Science Education, 31, 1091-1113. https://doi.org/10.1080/09500690801968656

Cherniss, C. (2000). Emotional Intelligence: What It Is and Why It Matters. In Proceedings of the Annual Meeting of the Society for Industrial and Organizational Psycholo$g y$, New Orleans, LA.

http://www.talentsmart.com/media/uploads/pdfs/eq-what-it-is.pdf

Dieker, L. A. et al. (2014). The Potential of Simulated Environments in Teacher Education: Current and Future Possibilities. Teacher Education and Special Education, 37, 21-33. https://doi.org/10.1177/0888406413512683

Durlak, J. A., Weissberg, R. P., Dymnicki, A. B., Taylor, R. D., \& Schellinger, K. B. (2011). The Impact of Enhancing Students' Social and Emotional Learning: A Meta-Analysis of School-Based Universal Interventions. Child Development, 82, 405-432. https://doi.org/10.1111/j.1467-8624.2010.01564.x

Hochschild, A. (1983). The Managed Heart. Berkeley and Los Angeles, California: University of California Press.

Inman, C., Wright, V. H., \& Hartman, J. A. (2010). Use of Second Life in K-12 and Higher Education: A Review of Research. Journal of Interactive Online Learning, 9, 44-63.

Jarmon, L., Traphagan, T., Mayrath, M., \& Trivedi, A. (2009). Virtual World Teaching, Experiential Learning, and Assessment: An Interdisciplinary Communication Course in Second Life. Computers \& Education, 53, 169-182.

https://doi.org/10.1016/j.compedu.2009.01.010

Jestice, R. J., \& Kahai, S. (2010). The Effectiveness of Virtual Worlds for Education: An Empirical Study. AMCIS 2010 Proceedings (p. 512). http://aisel.aisnet.org/amcis2010/512

Jones, I., \& Park, Y. (2015). Virtual Worlds: Young Children Using the Internet. In K. Heider, \& M. Renck (Eds.), Young Children and Families in the Information Age. Educating the Young Child (Advances in Theory and Research, Implications for Practice) (Vol. 10, pp. 3-13). Dordrecht: Springer. https://doi.org/10.1007/978-94-017-9184-7_1

Kim, A. J., \& Ko, E. (2012). Do Social Media Marketing Activities Enhance Customer Equity? An Empirical Study of Luxury Fashion Brand. Journal of Business Research, 65, 1480-1486. https://doi.org/10.1016/j.jbusres.2011.10.014

Kremenitzer, J. P., \& Miller, R. (2008). Are You a Highly Qualified, Emotionally Intelligent Early Childhood Educator? Young Children, 63, 106-108.

LaViola Jr., J. J. (2000). A Discussion of Cybersickness in Virtual Environments. ACM SIGCHI Bulletin, 32, 47-56. https://doi.org/10.1145/333329.333344

Merhi, O., Faugloire, E., Flanagan, M., \& Stoffregen, T. A. (2007). Motion Sickness, Video Games, and Head-Mounted Displays. Human Factors, 49, 920-934. https://doi.org/10.1518/001872007X230262

Miles, M. B., Huberman, A. M., \& Saldaña, J. (2013). Qualitative Data Analysis: A Methods Sourcebook (3rd ed.). Thousand Oaks, California: SAGE Publications, Inc.

Nissim, Y., \& Weissblueth, E. (2017). Virtual Reality (VR) as a Source for Self-Efficacy in Teachers Training. International Education Studies, 10, 52-59. https://doi.org/10.5539/ies.v10n8p52

Nissim, Y., Weissblueth, E., Scott-Webber, L., \& Amar, S. (2016). The Effect of a Stimulating Learning Environment on Pre-Service Teachers' Motivation and 21st Century Skills. Journal of Education and Learning, 5, 29-39. https://doi.org/10.5539/jel.v5n3p29

Osher, D., Kidron, Y., Brackett, M., Dymnicki, A., Jones, S., \& Weissberg, R. P. (2016). Advancing the Science and Practice of Social and Emotional Learning: Looking back 
and Moving forward. Review of Research in Education, 40, 644-681. https://doi.org/10.3102/0091732X16673595

Pantelidis, V. S. (2010). Reasons to Use Virtual Reality in Education and Training Courses and a Model to Determine When to Use Virtual Reality. Themes in Science and Technology Education, 2, 59-70.

Seale, J., Gibson, S., Haynes, J., \& Potter, A. (2015). Power and Resistance: Reflections on the Rhetoric and Reality of Using Participatory Methods to Promote Student Voice and Engagement in Higher Education. Journal of Further and Higher Education, 39, 534-552. https://doi.org/10.1080/0309877X.2014.938264

Twining, P. (2009). Exploring the Educational Potential of Virtual Worlds-Some Reflections from the SPP. British Journal of Educational Technology, 40, 19. https://doi.org/10.1111/j.1467-8535.2009.00963.x

Warburton, S. (2009). Second Life in Higher Education: Assessing the Potential for and the Barriers to Deploying Virtual Worlds in Learning and Teaching. British Journal of Educational Technology, 40, 414-426. https://doi.org/10.1111/j.1467-8535.2009.00952.x

Weissberg, R. P., Durlak, J. A., Domitrovich, C. E., \& Gullotta, T. P. (2015). Social and Emotional Learning: Past, Present and Future. In J. A. Durlak, C. E. Domitrovich, R. P. Weissberg, \& T. P. Gullotta (Eds.), Handbook for Social and Emotional Learning (pp 3-19). New York: Guilford.

Weissblueth, E., Nissim, Y., \& Amar, S. (2014). Educating for the Future: A Structured Course to Train Teachers for the 21st Century. Creative Education, 5, 900-912.

https://doi.org/10.4236/ce.2014.511103 